Кулик М. С., Кіриу Ф. І., Богданов М. Ю., Ханеш Хуссейн, Суровщев О. Ю.

Національний авіаційний університет. Україна, м. Київ

\title{
АДАПТИВНА СИСТЕМИ КЕРУВАННЯ ВІДРИВНИМИ ТЕЧІЯМИ В СТУПЕНЯХ ОСЬОВИХ ВЕНТИЛЯТОРІВ
}

В роботі наведені результати досліджень способу підвищення аеродинамічної навантаженості ступенів осьових вентиляторів (ОВ) та розширення діапазону їх стійкої роботи, за рахунок застосування адаптивної системи керування відривними течіями. Разом з тим, в роботі відображенні результати чисельних, параметричних досліджень ступеня ОВ та проведена оцінка зміни енергетичних параметрів ступеня вентилятора з адаптивною системою на зривному режимі роботи. В роботі наведені результати чисельного дослідження отримані шляхом комп'ютерного моделювання ступеня осьового вентилятора в комерційному програмному середовищі ANSYS. [dx.doi.org/10.29010/88.3]

Ключові слова: осьовий вентилятор; адаптивна система; відривні течї; комплексний акустичний резонатор.

\section{Вступ}

Підходи до вирішення комплексної багаторівневої проблеми - підвищення ефективності турбомашин, як складної технічної системи, з використанням методів активного керування обтікання лопаткових вінців для усунення явища відриву потоку та зниження рівня втрат знайшли відображення у роботах. Апробація літературних джерел показала, що активні методи аеродинамічного вдосконалення лопаткових машин $є$ досить ефективним способом усунення явища відриву потоку та зниження рівня втрат, що обумовлені не розрахунковим обтіканням лопаток і аеродинамічними слідами в проточній частині ступенів ОВ.

$\mathrm{y}$ даний час представлено значну кількість досліджень з використанням активних методів керування відривом потоку, що мають як переваги так і недоліки, проте слід зауважити, що представлені підходи мають значний недолік, який пов'язаний з енергетичними затратами на вдування або відсмоктування примежового шару. Це обумовлено тим, що процес вдування або відсортування має постійно діючий характер і не залежить від властивостей газодинамічної течії на заданому режимі роботи турбомашини. Як показують сучасні дослідження, відривна течія має періодичний характер. Частота та амплітуда коливань залежать від режиму роботи турбомашини. Підлаштовуючи роботу системи керування відривними течіями під режим роботи турбомашини та характеристики відри відривної течії, можливо досягти значного зниження енергетичних затрат. Технічно, реалізація такого підходу можлива шляхом застосування адаптивної, імпульсної системи керування відривними течіями.
Аналіз літературних джерел

Відомим методом активного керування відривом потоку зі зниженими енергетичними затратами є метод імпульсної інжекції або вдуву робочого тіла [1 - 4]. Раніше даний метод не вивчався через його високу вартість та значні енергетичні затрати, проте представляє значний науковий інтерес. Вчені NASA [5, 6] встановили, що мікровдув повітря через пористу стінку заданої геометрії є ефективним засобом впливу на відривні течії. Мікровдув зменшує коефіцієнт поверхневого тертя на $40 \%$ та збільшує показники інтегральних характеристик примежового шару [7]. Недоліком роботи є проведення досліджень для плоскої пластини із мікроотворами, тоді як реальні співвідношення між геометрією отворів і параметрами пограничного шару потребують детального вивчення.

Також відомо використання синтетичних струменів, як способу керування кінцевими вихровими течіями [8]. Пристрій складається 3 невеликої порожнини, об'єм якої змінюється в залежності від руху еластичної мембрани, та отвору (горла) для всмоктування і видуву робочого тіла.

Іншим підходом є застосування акустичних резонаторів [9]. Основний недолік такого підходу це однорежимність роботи.

Результати аналізу активних методів керування відривом потоку, показують, що іх застосування має безпосередній вплив на енергетичні параметри ступенів ОВ. Проте, враховуючи загальну картину кінцевих вихрових течій ступенів ОВ, використання одного методу управління є недостатнім, оскільки характеризується обмеженим діапазоном ефективності, тому виникає необхідність у формуванні 
комплексного підходу усунення явища відриву. В свою чергу, забезпечення можливості управління відривом потоку у певному експлуатаційному діапазоні формує підгрунтя до адаптивної складової методу управління. Тому метою роботи є формування комплексного підходу впливу на кінцеві вихрові структури та оцінка його впливу на енергетичні характеристики ступеня ОВ.

\section{Постановка задач дослідження}

Суть технічної задачі, що вирішується в даній роботі, полягає у зниженні інтенсивності пульсацій повітряного потоку в проточній частині ступеня вентилятора, що обумовлені відривом потоку 3 аеродинамічних поверхонь, а також запобігання його відриву. Застосування адаптивної системи керування відривними течіями, що інтегрована в спрямляючий апарат ступеня ОВ дозволить забезпечити підвищення рівня аеродинамічної навантаженості лопаток, розширення експлуатаційного діапазону ступеня ОВ.

Для досягнення мети досліджень в роботі вирішувались наступні задачі:

- Розробка блок-схеми адаптивної системи зменшення рівня кінцевих втрат об'єкта (ступеня ОВ);

- Проведення чисельного дослідження ступеня OB із застосуванням адаптивної системи;

- Проведення оцінки зміни енергетичних параметрів ступеня ОВ з використанням адаптивної системи.

\section{Методика чисельного дослідження ступеня ОВ}

Адаптивна система зменшення рівня кінцевих втрат в ступенях ОВ складається з наступних елементів: акустичного резонатору у вигляді двох порожнин, які об'єднані за допомогою перехідних каналів (рис. 2 a). У свою чергу, акустичний резонатор складається з отвору 1 - діаметром $D$, порожнини 2 - об'ємом $V$, горла 3 - висотою $h$. Над лопаткою встановлюється додаткова порожнина (надстаторна порожнина) 4 (рис. $2 a$ ), що розміщується над корпусом осьового вентилятору i виконує роль додаткового ресиверу (об’єму) для накопичення енергії робочого тіла. Вона, за допомогою перехідного каналу 3, з'єднується з резонансною порожниною 2 і утворює систему послідовно з'єднаних резонаторів. Адаптацію системи виконує рухомий елемент 5, що встановлено на верхній частині надстаторного кільця (рис. 2 б).

Блок-схему адаптивної системи керування кінцевими відривними течіями в ступені ОВ представлено на (рис. 3).

При моделюванні в якості розрахункової області був прийнятий ступінь ОВ з акустичним резонатором та інтегрованою адаптивною системою, що містить шість робочих лопаток, сім спрямляючих лопаток, систему резонаторів та контур адаптації (рис. $4 a$ ), де 1 - надстаторна порожнина у вигляді кільця, 2 - перехідні канали, ресивери накопичення робочого тіла 3, щілинних пристроїв 4 та

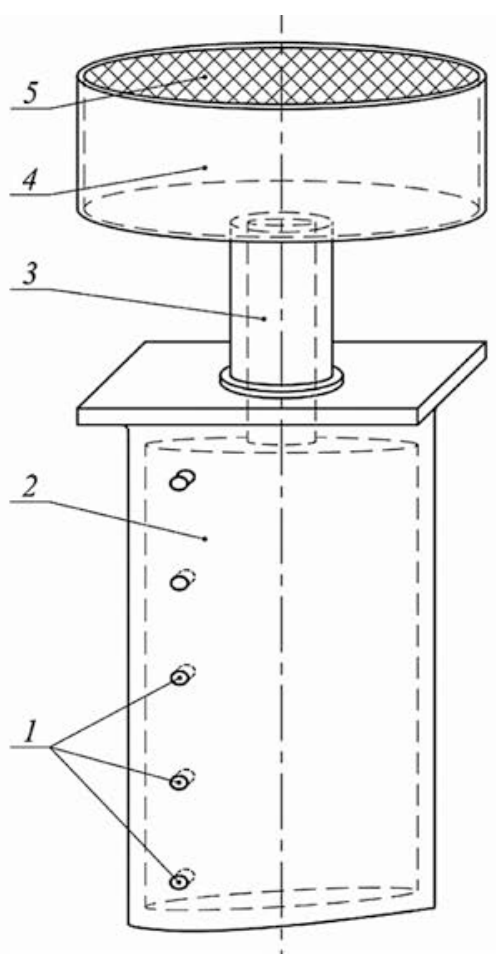

a)

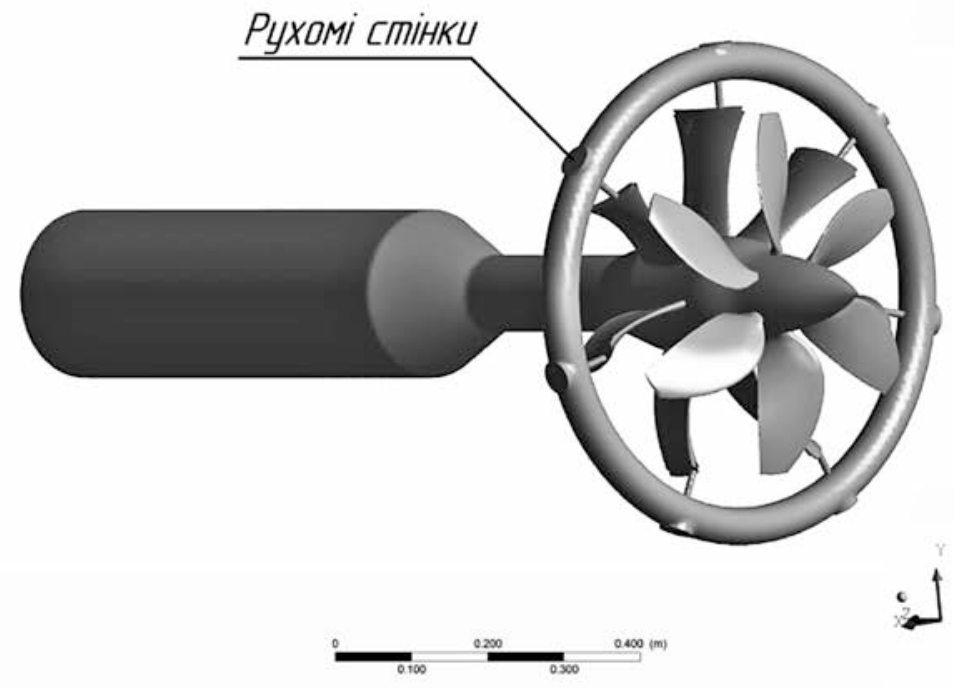

б)

Рис. 2. Модельний ступінь ОВ з адаптивною системою 
рухомих стінок 5. Перелік реперних точок ступеня ОВ наведено на (рис. 4 б).

Розрахункова модель (рис. 5) складалась 3 трьох доменів: нерухоме навколишнє середовище 1,2 - роторний і 3 - статорний домени.

Для моделювання стаціонарної в'язкої турбулентногї течії, використовувався тривимірний метод чисельної газодинаміки, реалізований в комерційному програмному продукті ANSYS-CFX 15.07. У даній програмі вирішуються нестаціонарні осереднені по Рейнольдсу рівняння Нав'є-Стокса замкнуті моделлю турбулентності.

Основними рівняннями, які забезпечують повний математичний опис потоку рідини, $є$

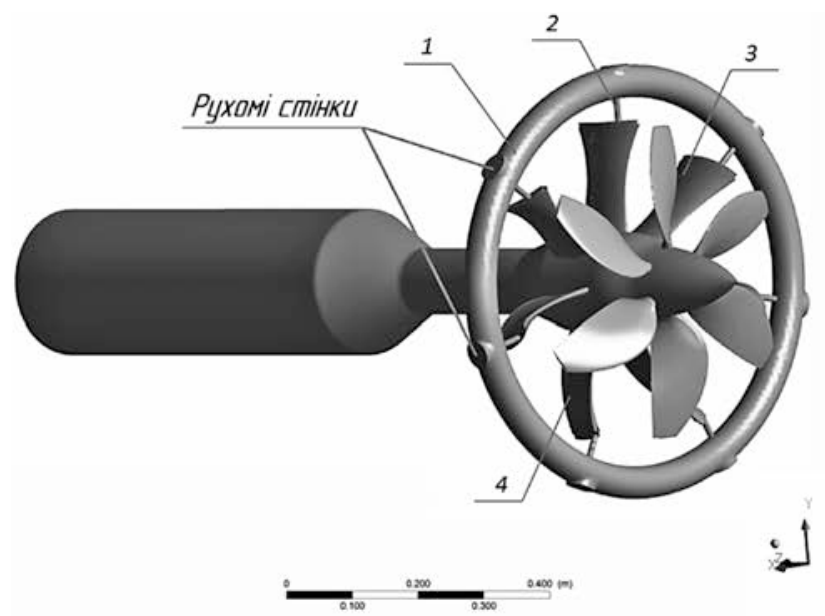

a)

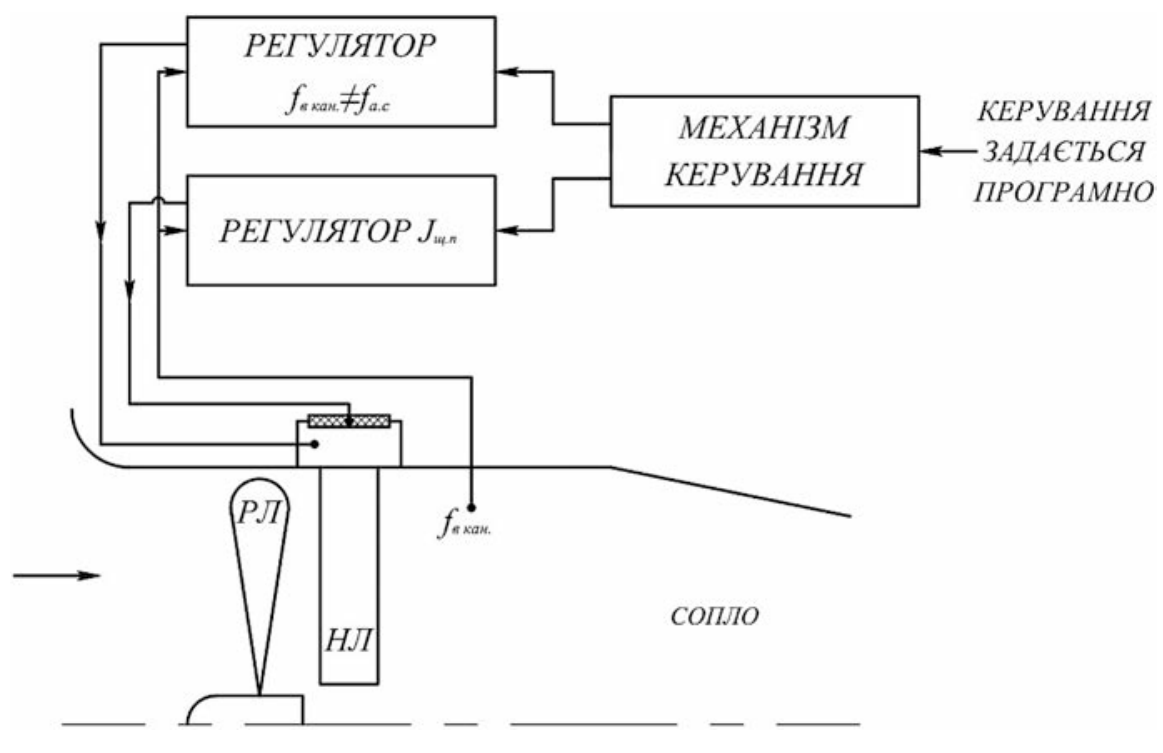

Рис. 3. Блок-схема адаптивної системи керування кінцевими відривними течіями ступеня ОВ

Рис. 4. Модельний ступінь ОВ з акустичним резонатором, контуром адаптації та розміщенням реперних точок

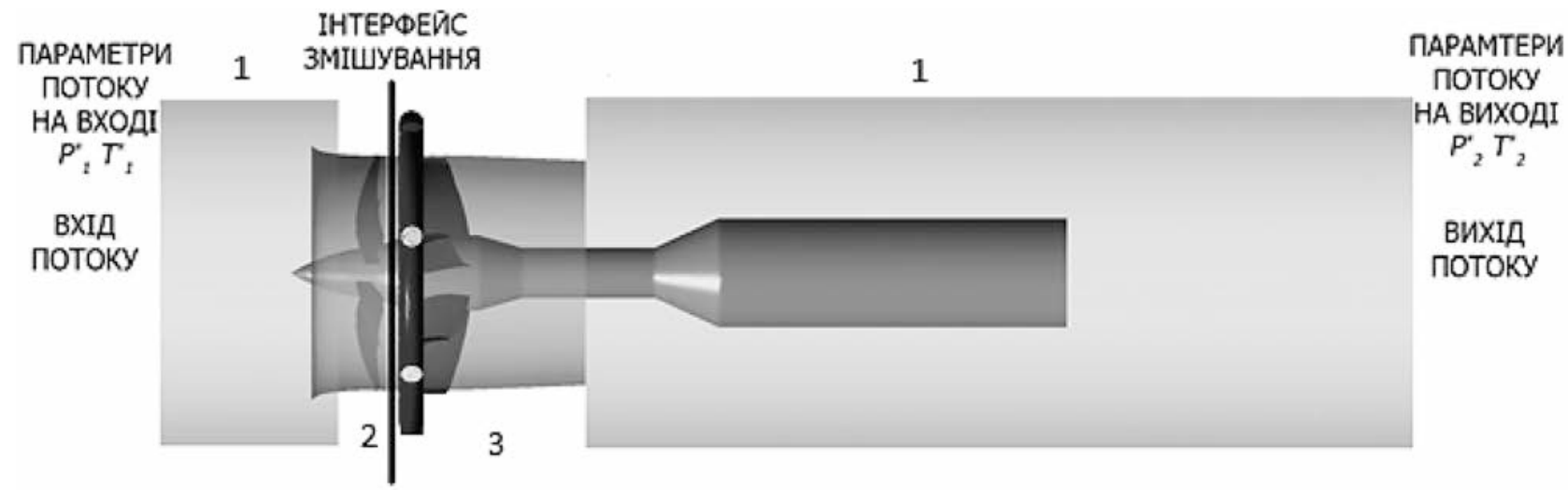

Рис. 5. Схема розрахункової області ступеня ОВ з акустичним резонатором та контуром адаптації 
рівняння: збереження маси (1); імпульсу (2); скаляра (енергіi) (3)

$$
\begin{gathered}
\frac{\partial \rho}{\partial t}+\frac{\partial}{\partial x_{j}}\left(\rho u_{j}\right)=0 \\
\frac{\partial}{\partial t}\left(\rho u_{j}\right)+\frac{\partial}{\partial x_{j}}\left(\rho u_{i} u_{j}\right)=\frac{\partial p^{*}}{\partial x_{i}}+\frac{\partial}{\partial x_{j}}\left(\mu _ { e f f } \left(\frac{\partial u_{i}}{\partial x_{j}}+\right.\right. \\
\left.\left.+\frac{\partial u_{j}}{\partial i}\right)-\frac{2}{3} \mu_{e f f} \frac{\partial u_{i}}{\partial x_{j}} \delta_{i j}\right)
\end{gathered}
$$$$
\frac{\partial}{\partial t}(\rho H)+\frac{\partial}{\partial x_{j}}\left(\rho u_{i} H\right)=-\frac{\partial p^{*}}{\partial t}+\frac{\partial}{\partial x_{j}}\left(\lambda \frac{\partial T}{\partial x_{j}}+\right.
$$$$
\left.+\frac{\mu_{t}}{P r_{i}} \frac{\partial h}{\partial x_{j}}\right)+\frac{\partial}{\partial x_{j}}\left\{u _ { i } \left[\mu_{e f f}\left(\frac{\partial u_{i}}{\partial x_{j}}+\frac{\partial u_{j}}{\partial x_{i}}\right)-\right.\right.
$$$$
\left.\left.-\frac{2}{3} \mu_{e f f} \frac{\partial u_{k}}{\partial x_{k}} \delta_{i j}\right]+\mu \frac{\partial k}{\partial x_{j}}\right\},
$$

$$
\text { де } \mu_{e f f}=\mu+\mu_{t}, p^{*}=p+\frac{2}{3} \rho k \text {. }
$$

Для замыкання рівнянь в работі застосовувалась модель турбулентной в'язкості SST Ментера 3 стандартним набором констант $\alpha_{\infty}^{*}=1, \alpha_{\infty}=0.52$, $\alpha_{0}=1 / 9, \alpha_{1}=0.31, \beta_{\infty}^{*}=0.09, \beta_{i 1}=0.075, \beta_{i 2}=0.0828$, $\sigma_{k 1}=1.176, \sigma_{k 2}=1.0, \sigma_{\omega 1}=2.0, R_{\beta}=8, R_{k}=6, \zeta^{*}=1.5$, $M_{t 0}=0.25[18,19]$.

В'язкість газу моделювалась за законом Свізерленда [20].

Розрахункова сітка моделювалась як блочна структура та складається з структурованої сітки із чотирикутними елементами в межах примежового шару і неструктурованої сітки з трикутними елементами в усій розрахунковій зоні. На поверхні лопаток в області примежового шару, проводилось згущення сітки з висотою першого ряду сітки 0,01 , фактором росту 1,2 та кількістю рядів, що становить 15. Загальна кількість елементів розрахункової сітки складала в середньому $7 \cdot 10^{6}$ елементів усіх розрахункових перерізів

\section{Результати досліджень}

3 метою дослідження характеру відривних течій та впливу на них системи керування, дослідження адаптивної системи ступеня ОВ проводились на зривному режимі роботи ступеня. Характеристики ступеня порівнювалися на номінальному та на зривному режимах роботи.
Зміна параметрів значень повного тиску $p^{*}$ та осьової швидкості $C_{\text {сер }}$ на зривному режимі роботи ступеня ОВ з адаптивною системою (рис. $6 a$ та б)) характеризується зміною амплітуд розподілу параметрів ступеня. Амплітуда коливань значень повного тиску $p^{*}$

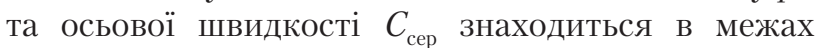
$p^{*}=102939 \div 103233$ Па і $C_{\text {сер }}=41,76 \div 43,91 \mathrm{~m} / \mathrm{c}$. Середнє значення повного тиску $p^{*}$ та осьової швидкості $C_{\text {сер }}$ складає $p^{*}=1758,87$ Па і $C_{\text {сер }}=42,21 \mathrm{~m} / \mathrm{c}$.

Застосування адаптивної системи зменшення рівня кінцевих втрат на зривному режимі роботи ступеня ОВ дозволяє зменшити амплітуду високочастотних та низькочастотних коливань значень повного тиску $p^{*}$ і осьової швидкості $C_{\text {сер }}$ на $15 \%$ в порівнянні з «базовим» ступенем осьового вентилятора.

Слід зауважити, що робота адаптивної системи має імпульсний характер. Дане явище добре прослідковується на кривій розподілу значень осьової швидкості (рис. 7б). Крива розподілу значень, що відповідає частоті коливань $f \cong 71,4$ Гц, є вдувом робочого тіла в примежовий шар, подальша зміна значень відповідає накопиченню робочого тіла адаптивною системою.

Значення ККД ступеня ОВ з адаптивною системою при зривному режимі роботи дорівнюе $\eta_{\text {ст. }}=0,67$, що на 7\% більше ніж значення ККД «базового» ступеня ОВ при зривному режимі. Значення тяги ступеня ОВ з адаптивною системою при зривному режимі дорівнює $P_{\Sigma}=270,0 \mathrm{H}$, що більше в порівнянні із значеннями тяги «базового» ступеня ОВ на 4,5\%. Параметри ступеня ОВ з адаптивною системою на зривному режимі роботи вказані в табл. 1.

Картина ліній току, що видуваються зі щілинних каналів та вихроутворень при зривному режимі роботи ступеня осьового вентилятора $з$ адаптивною системою керування відривними течіями представлена на рис. 8. Через отвори почергово відбувається видування та всмоктування повітря з поверхні лопаток спрямляючого апарату. Частота видування та всмоктування корегується алгоритмом адаптивної системи в залежності від частоти пульсації потоку за спрямляючим апаратом ступеня ОВ.

Таблиця 1

\section{Значення основних параметрів ступеня ОВ з адаптивною системою зривному режимі}

\begin{tabular}{|c|c|}
\hline $\begin{array}{c}\text { 3начення параметрів при зривному режимі роботи } \\
\text { ступеня ОВ з адаптивною системою }\end{array}$ \\
\hline$p^{*}$, Па & 103083.87 \\
\hline$T^{*}, \mathrm{~K}$ & 302.03 \\
\hline$C_{\text {сер }}, \mathrm{MC}$ & 42.21 \\
\hline$G_{\text {ст.в }}, \mathrm{KГC}$ & 4.83 \\
\hline$M_{\text {ст.в }}, \mathrm{H}$ м & 19.52 \\
\hline$P_{\Sigma}, \mathrm{H}$ & 270.0 \\
\hline$\eta_{\text {ст.в }}$ & 0.67 \\
\hline
\end{tabular}




\section{3/2019 ТЕХАлогические \С}

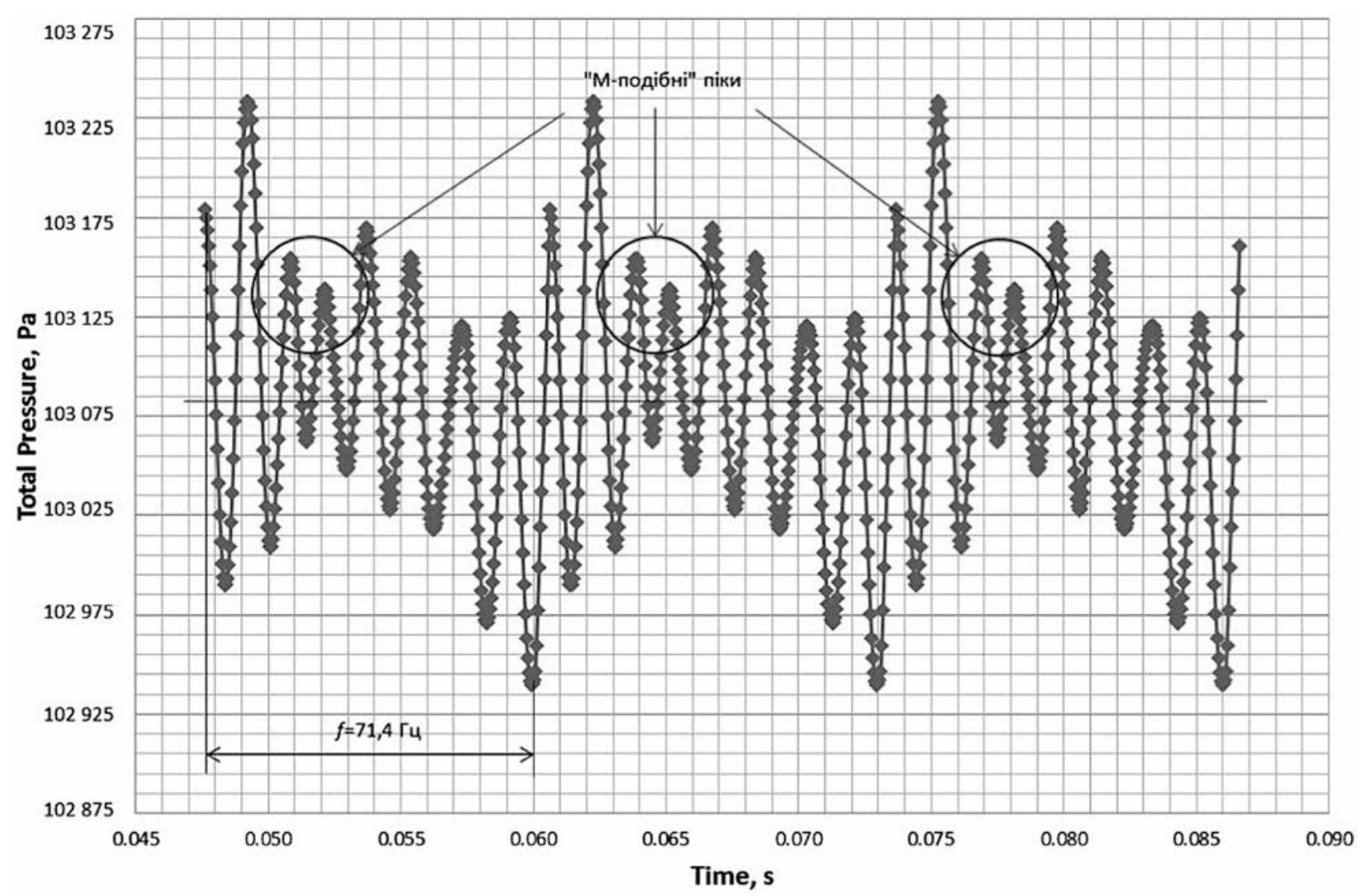

a)

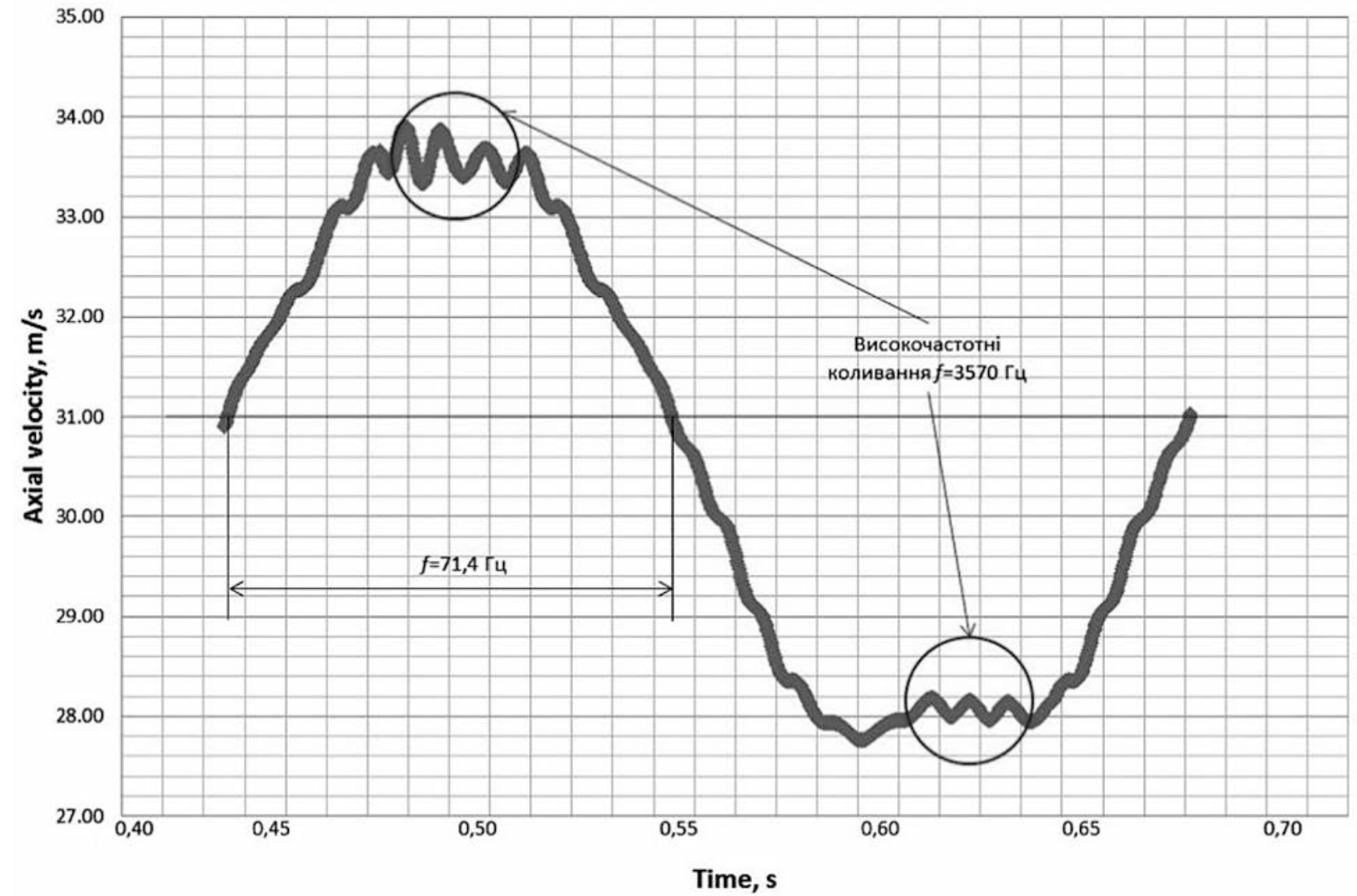

б)

Рис. 7. Зміна значень повного тиску $P^{*} a$ ) та осьової швидкості $C_{\text {сер }} \sigma$ ) при зривному режимі роботи ступеня ОВ з адаптивною системою 


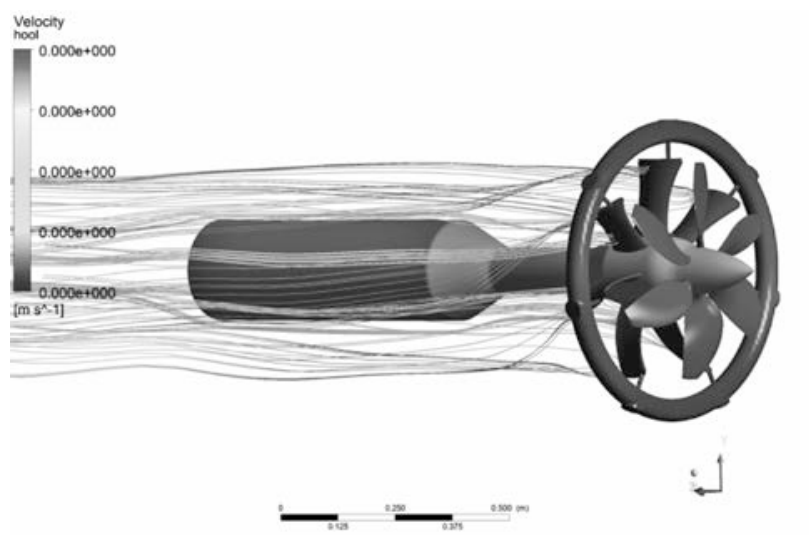

a)

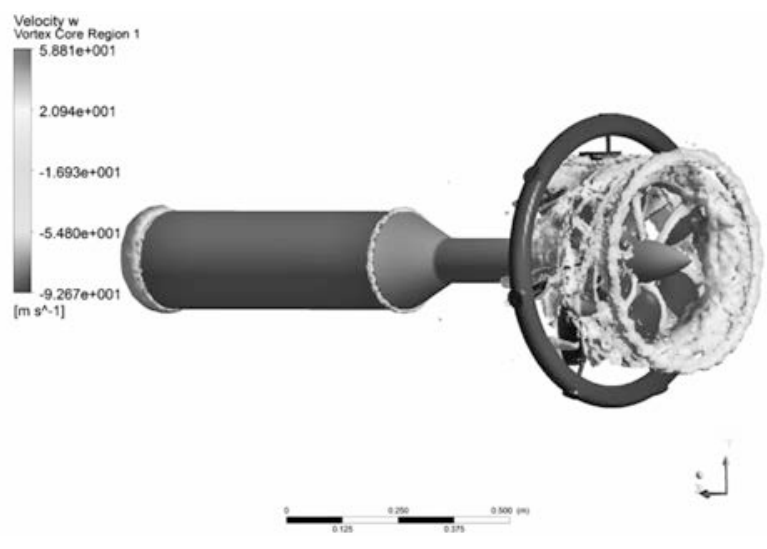

б)

Рис. 8. Лінії току $a$ ) та зони вихороутворення б) на зривному режимі роботи ступеня ОВ з адаптивною системою

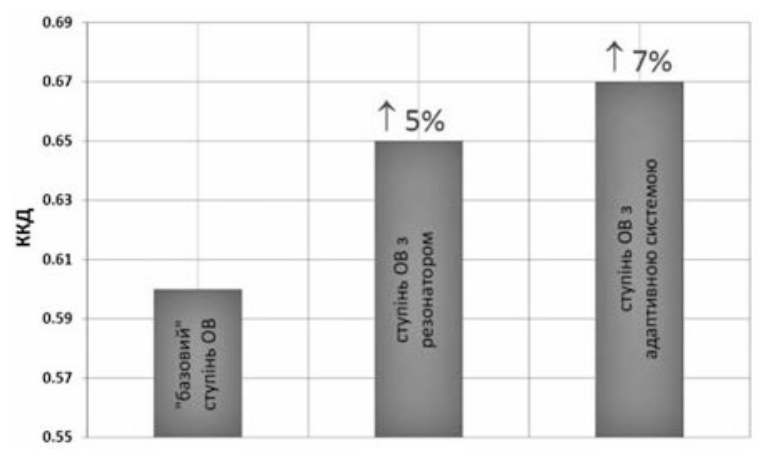

a)

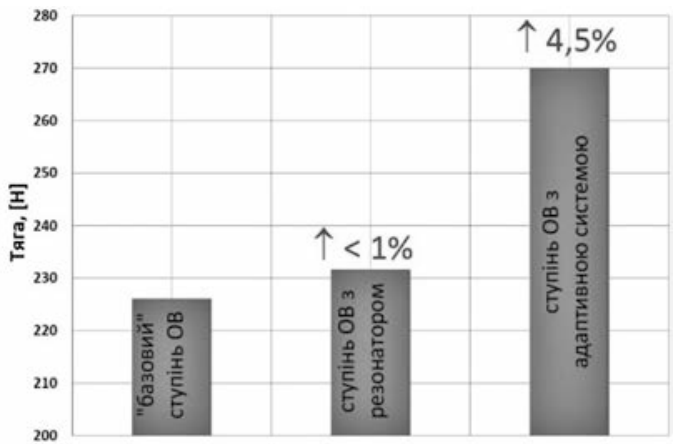

б)

Рис. 9. Гістограми розподілу енергетичних параметрів ступеня $a$ ) розрахунковий режим $\sigma$ ) зривний режим

Осереднені параметри досліджуваного ступеня осьового вентилятора 3 адаптивною системою представлені в таблиці 1.

Виходячи $з$ порівнянь характеристик (рис. $9 a$ та б) «базового» ступеня ОВ та ступеня із застосуванням адаптивної системи можемо прийти до висновку, що на зривному режимі роботи ступеня осьового вентилятора, застосування адаптивної системи призводить до приросту значень ККД ступеня на $7 \%$ та тяги на $4,5 \%$.

\section{Висновки}

Результати досліджень ступеня з адаптивною системою на зривному режимі характеризуються зменшенням амплітуди високочастотних та низькочастотних коливань значень повного тиску $p^{*}$ і осьової швидкості $C_{\text {сер }}$ на $15 \%$ в порівнянні з «базовим» ступенем осьового вентилятора. Робота адаптивної системи має імпульсний характер, що добре прослідковується на кривій розподілу значень осьової швидкості. Крива розподілу значень, що відповідає частоті коливань $f \cong 71,4$ Гц, є вдувом робочого тіла в примежовий шар, а подальша зміна значень відповідає накопиченню робочого тіла адаптивною системою.
Середнє значення повного тиску $p^{*}$ та осьової швидкості $C_{\text {сер }}$ складає $p^{*}=1758,87$ Па і $C_{\text {сер }}=42,21 \mathrm{~m} / \mathrm{c}$.

В цілому застосування адаптивної системи, в якій в якості активного елементу використовується акустичний резонатор зі змінною частотою власних коливань, призводить в середньому до приросту ККД ступеня на 7 \% та тяги на 4,5\%.

В перспективі, якщо застосовувати акустичний резонатор зі змінним об'ємом акустичної порожнини, можливо досягти ще більшої ефективності.

\section{Література}

[1] Абзалилов Д. Ф., Валитов Н. Б., Ильинский Н. Б. Моделирование устройств активного управления пограничным слоем, предотвращающих отрыва потока на крыловых профилях // Материалы XVI Международной конференции по вычислительной механике и современным прикладным программным системам (ВМСППС2009), 25-31 мая 2009, Алушта. - М.: Издво МАИ-ПРИНТ, 2009. - С. 45-47.

[2] Голованов А. Н. Влияние акустических возмущений на свободно-конвективного течения // Прикладная механика и техническая физика. - 2006. Т. 47., № 5. - C. 27-33. 
[3] Занин Б. Ю., Зверков И. Д., Козлов В. В., Павленко А. М. О новых методах управления дозвуковыми отрывными течениями // Вестник Новосибирского государственного университета. - 2007. Т. 2, № 1. C. $10-18$.

[4] Frank G. Collins, James Zelenevits. Influence of Sound upon Separated Flow over Wings // AIAA Journal. 2013., № 3 (1975). - pp. 408-410.

[5] Evaluation of Pulsed \& Steady Blowing Flow Control in a Slotted Leading Edge Configuration by Colin Patterson. School of engineering Tufts University Medford, MA May 2011

[6] Active and passive flow control over the flight deck of small naval vessels by Daniel M. Shafer. Virginia
Polytechnic Institute and State University. Blacksburg, Virginia. http://hdl.handle.net/10919/32427

[7] Flow control over a circular arc airfoil by periodic blowing by José M. Rullán. Virginia Polytechnic Institute and State University. Blacksburg, Virginia.

https://pdfs.semanticscholar.org/8f02/033bf334f732 bf7acbc531a3980fcf8c97e3.pdf

[8] Корнилов В. И., Бойко А. В. Управление турбулентным пограничным слоем пассивными и активными методами. Успехи и проблемы // International Conference on the Methods of Aerophysical Research ICMAR. - 2010. C. 1-9.

[9] F. Urzynicok and H. Fernholz, «Flow-induced acoustic resonators for separation control,» in AIAA 2002

Kulyk M. S., Kirchu F. I., Bogdanov M. Yu., Hunesh Hussein, Surovtsev O. Yu.

National Aviation University. Ukraine, Kyiv

\section{ADAPTIVE CONTROL SYSTEMS OF EXTRACTIVE FLOWS IN THE RATES OF AXIAL FANS}

The results of investigations of the method of increasing the aerodynamic loading of the degrees of axial fans (OV) and expanding the range of their stable operation due to the use of an adaptive system for controlling the discontinuous flows are presented in the paper. The studies were performed with the change of amplitudes of high-frequency and low-frequency oscillations of values of full pressure and axial velocity by $15 \%$ in comparison with the "basic" degree of axial fan, provided the impulse nature of the adaptive system. At the same time, the results of numerical, parametric studies of the degree of $\mathrm{OV}$ are presented in the work and the change of the energy parameters of the degree of the fan with the adaptive system on the breakdown mode is estimated. The results of numerical research are obtained by computer simulation of the degree of axial fan in a commercial software environment ANSYS. [dx.doi.org/10.29010/88.3]

Keywords: axial fan; adaptive system; detachable currents; integrated acoustic resonator.

\section{References}

[1] Abzalilov D. F. Modelirovanie ustrojstv aktivnogo upravleniya pogranichny`m sloem, predotvrashhayushhikh otry`va potoka na kry`lovy`kh profilyakh / D. F. Abzalilov, N. B. Valitov, N. B. Il`inskij // Materialy`XVI Mezhdunarodnoj konferenczii po vy`chislitel`noj mekhanike i sovremenny`m prikladny`m programmny`m sistemam (VMSPPS2009), 25-31 maya 2009, Alushta. - M.: Izd-vo MAI-PRINT, 2009. - S. 45 - 47.

[2] Golovanov A. N. Vliyanie akusticheskikh vozmushhenij na svobodno-konvektivnogo techeniya // Prikladnaya mekhanika i tekhnicheskaya fizika. - 2006. T. 47., \# 5. - S. 27 - 33.

[3] Zanin B. Yu. O novy`kh metodakh upravleniya dozvukovy`mi otry`vny`mi techeniyami / B. Yu. Zanin, I. D. Zverkov, V. V. Kozlov, A. M. Pavlenko // Vestnik Novosibirskogo gosudarstvennogo universiteta. - 2007. T. 2, \# 1. - S. 10 - 18.

[4] Frank G. Collins. Influence of Sound upon Separated Flow over Wings / Frank G. Collins, James Zelenevits // AIAA Journal. - 2013., № 3 (1975). - pp. 408 - 410.

[5] Evaluation of Pulsed \& Steady Blowing Flow Control in a Slotted Leading Edge Configuration by Colin Patterson. School of engineering Tufts University Medford, MA May 2011

[6] Active and passive flow control over the flight deck of small naval vessels by Daniel M. Shafer. Virginia Polytechnic Institute and State University. Blacksburg, Virginia. http://hdl.handle.net/10919/32427

[7] Flow control over a circular arc airfoil by periodic blowing by Josŭ M. Rullбn. Virginia Polytechnic Institute and State University. Blacksburg, Virginia. https://pdfs.semanticscholar.org/8f02/033bf334f732bf7acbc531a3980fcf8c97e3.pdf

[8] Kornilov V. I. Upravlenie turbulentny`m pogranichny`m sloem passivny`mi i aktivny`mi metodami. Uspekhi i problemy`/ V. I. Kornilov, A. V. Bojko // International Conference on the Methods of Aerophysical Research - ICMAR. - 2010. C. 1 - 9.

[9] F. Urzynicok. "Flow-induced acoustic resonators for separation control," / F. Urzynicok, H. Fernholz // in AIAA 2002. 